\title{
The Effect of MRP5-Expression on Human Erythroleukemia (HEL) Cell Growth and cGMP Levels
}

\author{
Xiaoyan Chen, Roy A. Lysaa, Ragnhild Jaeger, Emanuel Boadu, Georg Sager \\ Medical Pharmacology and Toxicology, Department of Medical Biology, Faculty of Health Sciences, Arctic \\ University of Norway, Tromso, Norway \\ Email: georg.sager@uit.no
}

Received 21 December 2015; accepted 18 January 2016; published 21 January 2016

Copyright (C) 2016 by authors and Scientific Research Publishing Inc. This work is licensed under the Creative Commons Attribution International License (CC BY). http://creativecommons.org/licenses/by/4.0/

(c) (i) Open Access

\begin{abstract}
Background: Previous studies of patients with acute leukemia showed that plasma cGMP levels were markedly elevated before treatment, fell after successful therapy but increased after relapse. In many cells high concentrations of GMP have an antiproliferative effect. The cellular cGMP extrusion from cancer cells may represent an acquired resistance against an endogenous antiproliferative signal molecule. Multidrug resistance associated protein 5 (MRP5) has been identified as an important cGMP transporter. Methods: A human erythroleukemia cell line (HEL) was used to study the impact of cGMP and cGMP-elevating compounds like theophylline, sodium nitroprusside (SNP) and sodium nitrite $\left(\mathrm{NaNO}_{2}\right)$. MRP5 was overexpressed in HEL cells by transfection. Concentrations of cGMP were determined with RIA or HPLC and cell densities were determined by cytometry. Results: The concentration ratio between extra- and intracellular cGMP concentrations was >1, meaning that HEL cells extruded cGMP against a concentration gradient and MRP5 was identified in these cells. In some cell types butyrate increases cellular cGMP levels by stimulating soluble guanylyl cyclase (sGC) and thereby the cellular efflux. This effect did not exist for HEL cells. MRP5 transfected HEL cells which were exposed to cGMP was clearly more sensitive to the antiproliferative effect than the wild type. On the other hand, exposing the transfected HEL cells to cGMP-elevating agents (theophylline, SNP and $\mathrm{NaNO}_{2}$ ) showed less sensitivity than the wildtype. Conclusion: This study supports the idea that some cancers acquire resistance against endogenous signal molecules with antiproliferative potency.
\end{abstract}

\section{Keywords}

Cyclic GMP, MRP5, Resistance, Cancer, Growth, Regulation

How to cite this paper: Chen, X.Y., Lysaa, R.A., Jaeger, R., Boadu, E. and Sager, G. (2016) The Effect of MRP5-Expression on Human Erythroleukemia (HEL) Cell Growth and cGMP Levels. Pharmacology \& Pharmacy, 7, 64-70.

http://dx.doi.org/10.4236/pp.2016.71009 


\section{Introduction}

The observation that some cancer types were associated with increased extracellular cGMP levels during active disease forwarded the idea of an acquired resistance against an endogenous molecule with antiproliferative properties. This phenomenon has been well documented for leukemia and some gynecologic cancers. In patients with acute leukemia the plasma cGMP levels were markedly elevated before treatment, fell after successful therapy but increased after relapse [1]. In cancer of the uterine cervix, the urinary cGMP levels were elevated in untreated cancer but decreased after successful treatment [2]-[4]. In a comparison between a control group ( $\mathrm{n}=$ 83) and women with epithelial ovariancancer $(n=92)$ elevated urinary cGMP levels were evident among 53\% of the patients [5]. In a two-center follow-up study serial samples from 60 patients with ovarian cancer were monitored up to 2 years after the start of therapy [6]. Urine cGMP levels were significantly higher in those patients with poorly differentiated tumors. Serial measurements made it possible to predict relapse in $64 \%$ prior to other clinical signs. However, these studies showed that low sensitivity and poor specificity made extracellular cGMP as tumor marker unsuitable for screening purposes.

Efflux of cGMP from hRBC (human erythrocytes) was composed of high and low affinity transport [7] and the cGMP transporter was identified as MRP5 (the ATP-Binding-Cassette transporter ABCC5) [8]. Cyclic AMP was not able to compete with the high affinity ATP-dependent cGMP transport [9] [10] but inhibited the low affinity transport [10]. Based on the observations in hRBC and the effects of elevating cGMP levels in HEK293 cells [11] we employed a human hemopoietic cell line; human erythroleukemia cells (HEL) [12] for the present study. Since butyrate increases cGMP efflux in some cells [13] the effect on HEL cell growth and elevation of cGMP levels was characterized. In addition, HEL-cells were transfected with MRP5 to test the hypothesis whether increased cGMP efflux may represent acquired resistance against endogenous growth control.

\section{Materials and Methods}

\subsection{Chemicals}

The following chemicals were obtained from Sigma-Aldrich: Guanosine 3', 5'-cyclic monophosphate (cGMP), bromo-guanosine 3', 5'-cyclic monophosphate (Br-cGMP), sodium nitroprusside (SNP), sodium nitrite $\left(\mathrm{NaNO}_{2}\right)$, theophylline, butyric acid, dithiothreitol. Ethidium bromide was purchased from Biological Molecular Reagents, hygromycin B from Life Technologies Inc. All other chemicals were of analytical grade.

\subsection{Cell Culture}

Human erythroleukemia (HEL) wildtype (wt) cells were obtained from European Collection of Cell Cultures. The cells were seeded at $3-4 \times 10^{4} / \mathrm{ml}$ in RPMI 1640 supplemented with $10 \%$ FCS, $1 \%$ L-glutamine with daily renewal. The cell densities were determined in a cytometer and viability assessed with the trypan blue exclusion test. After seeding, a short lag phase ( 1 - 2 days) was observed before the $\mathrm{HEL}_{\mathrm{wt}}$ cells entered a logarithmic growth phase. Under these experimental conditions the doubling time of was $25.1 \pm 2.5 \mathrm{~h}$.

\subsection{Transfection of HEL Cells with MRP5}

HEL cells were stably transfected with the plasmid by liposome-mediated method [14] with Qiagen plasmid kits. The plasmid pc DNA 3.1/Hygro-MRP5 cDNA was obtained from Professor Dietrich Keppler, Heidelberg, Germany. The plasmid in E. coli cells were extracted and purified. The transfection experiments were performed two times (MRP5 ${ }^{1}$ and MRP5 $^{2}$ ). The expression of the MRP5 proteins was verified using Western Blot. ECL This method included Western blotting detection reagents from Amersham, UK with anti-MRP5 (human) MAb (M5I-1) and peroxidase conjugated anti-rat IgG and HRP-conjugated anti-biotin antibody. Figure 1 shows a 180 $\mathrm{kDa}$ band of MRP5 from each lane and with clearly more MRP5 proteins in HEL-MRP5 ${ }^{1}$ and HEL-MRP5 ${ }^{2}$ than in the HEL $\mathrm{wt}_{\mathrm{wt}}$ cells. The doubling time of HEL-MRP5-cells was similar to wildtype (27.0 $\left.\pm 1.6 \mathrm{~h}\right)$.

\subsection{Cyclic GMP Assay}

Radioimmunoassay (RIA) was used to determine intra- and extracellular concentrations of cGMP in some of the experiments. The cGMP-analysis with Amerlex-M $\left[{ }^{125} \mathrm{I}\right]$ kits was performed as recommended by the manufacturer (Amersham International plc). High extracellular cGMP concentrations were determined in a HPLC-assay 


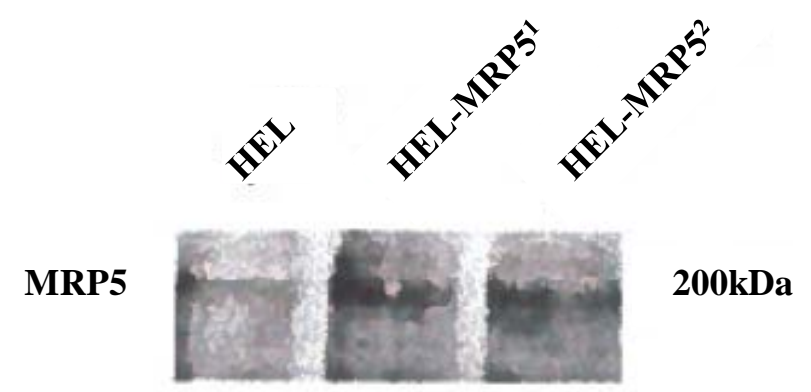

Figure 1. Western blot with expression of MRP5 in HEL cells. The band of $200 \mathrm{kDa}$ represents MRP5 and the protein amount (from identical number cells) was higher in HEL-MRP5 ${ }^{1}$ and HEL-MRP5 ${ }^{2}$ than HEL $_{w t}$ cells. HEL$\mathrm{MRP}^{1}{ }^{1}$ and HEL-MRP5 ${ }^{2}$ represent the first and second time transfected HEL cells, respectively.

with UV detection (254 $\mathrm{nm})$ as previously described [11].

\subsection{Statistics and IC ${ }_{50}$-Values}

Descriptive statistics were presented as mean \pm SE. The concentration inhibition curves were analyzed according to Chou [15] to obtain $\mathrm{IC}_{50}$-values.

\section{Results}

\subsection{Butyrate and Cell Growth}

Butyrate may increase cellular cGMP efflux in some cell types [13] but also modulate cell growth; for review see [16]. In the present study, butyrate concentrations up to $100 \mu \mathrm{M}$ had minimal effect on HEL cell growth compared to baseline. However, concentrations above $100 \mu \mathrm{M}$ showed a marked reduction in cell densities with an estimated $\mathrm{IC}_{50}$-value of $470 \mu \mathrm{M}$. The effect of butyrate on intra- and extracellular cGMP levels were determined below growth-modulating concentrations. Inhibition of PDE (cyclic nucleotide phosphodiesterase) by theophylline did not change cGMP levels markedly (Table 1). After sGC (soluble guanylyl cyclase) stimulation by SNP and $\mathrm{NaNO}_{2}$ the intracellular cGMP levels appeared to be raised somewhat. However, the extra- to intracellular concentration ratio did not indicate any major changes in cellular cGMP efflux.

\subsection{Exogenous cGMP and Cell Growth}

The possibility that cGMP modulated cell growth differently was explored. The cells were cultured with exogenously added cGMP to achieve concentrations in the medium from 0 to $1000 \mu \mathrm{M}$. Cyclic GMP inhibited both HEL $\mathrm{wt}_{\mathrm{wt}}$ and HEL-MRP5 cell growth in a concentration-dependent manner (Figure 2). However, exogenous cGMP was apparently less effective as inhibitor of MRP5-transfected cell growth. The $\mathrm{IC}_{50}$-value for $\mathrm{HEL}_{\mathrm{wt}}$ was estimated to be $250 \mu \mathrm{M}$, whereas the corresponding values for HEL-MRP5 ${ }^{1}$ and HEL-MRP5 ${ }^{2}$ were $750 \mu \mathrm{M}$ and $3 \mathrm{mM}$, respectively. The intra- and extracellular cGMP levels were assayed by HPLC. However, the intracellular levels were below the limit of detection, and $24 \mathrm{~h}$ after addition the extracellular cGMP levels were reduced with $50 \%-60 \%(100 \mu \mathrm{M})$ and $5 \%-10 \%(1000 \mu \mathrm{M})$. It was not possible to see any effect of transfection on the extracellular levels with the methods employed.

\subsection{SNP-Stimulated Soluble Guanylyl Cyclase and Cell Growth}

After exposure to SNP, the HEL $\mathrm{wt}_{\mathrm{wt}}$ cell densities were reduced concentration-dependently (Figure 3). After seven days with $100 \mu \mathrm{M}$ SNP the cell densities fell to $71.1 \% \pm 13.9 \%$ for $\mathrm{HEL}_{\mathrm{wt}}, 33.8 \% \pm 9.3 \%$ and $52.2 \% \pm 5.0 \%$ (mean $\pm \mathrm{SE}$ ) for HEL-MRP5 ${ }^{1}$ and HEL-MRP5 ${ }^{2}$, respectively. The $\mathrm{IC}_{50}$-values were estimated to be $5 \mathrm{mM}$ for the $\mathrm{HEL}_{\mathrm{wt}}$-cells. The transfected cell lines were more sensitive to SNP (Figure 3). However, even if the transfections were conducted with an identical protocol a clear difference in sensitivity was observed. The estimated IC $_{50}$-values were $20 \mu \mathrm{M}$ and $130 \mu \mathrm{M}$ for HEL-MRP5 ${ }^{1}$ and HEL-MRP5 ${ }^{2}$, respectively. 
Table 1. The effect of butyrate on HEL-cell cGMP levels in absence or presence of theophylline, SNP, $\mathrm{NaNO}_{2}$. The cells were seeded at a concentration of $4 \times 10^{5}$ cells $/ \mathrm{ml}$. They were cultured in a medium described in methods and supplemented with 1 and $100 \mu \mathrm{M}$ butyrate, respectively. After $24 \mathrm{~h}$ the cells were transferred to new tubes and incubated for 36 min in the absence or in presence of $1 \mathrm{mM}$ theophylline. Soluble guanylyl cyclase was stimulated with $10 \mu \mathrm{M}$ SNP or $10 \mathrm{mM} \mathrm{NaNO}_{2}$ for $6 \mathrm{~min}$ at $37^{\circ} \mathrm{C}$. Intra- and extracellular cGMP levels (given as fmol/10 4 cells) were quantified by radioimmunoassay.

\begin{tabular}{|c|c|c|c|}
\hline \multicolumn{4}{|c|}{ Intracellular cGMP (fmol/10 $10^{4}$ cells) } \\
\hline Butyrate & 0 & $1 \mu \mathrm{M}$ & $100 \mu \mathrm{M}$ \\
\hline Control & $8.3 \pm 0.8$ & $7.2 \pm 0.8$ & $9.8 \pm 1.7$ \\
\hline Theophylline & $7.4 \pm 0.7$ & $9.4 \pm 1.2$ & $9.2 \pm 0.8$ \\
\hline Theophylline + SNP & $10.5 \pm 1.0$ & $13.1 \pm 1.5$ & $12.9 \pm 1.6$ \\
\hline Theophylline $+\mathrm{NaNO}_{2}$ & $9.0 \pm 0.7$ & $11.0 \pm 0.8$ & $13.7 \pm 1.5$ \\
\hline \multicolumn{4}{|c|}{ Extracellular (fmol $/ 10^{4}$ cells) } \\
\hline Butyrate & 0 & $1 \mu \mathrm{M}$ & $100 \mu \mathrm{M}$ \\
\hline Control & $12.1 \pm 1.9$ & $10.0 \pm 1.4$ & $13.4 \pm 2.2$ \\
\hline Theophylline & $12.1 \pm 1.5$ & $13.2 \pm 2.0$ & $13.5 \pm 2.1$ \\
\hline Theophylline + SNP & $13.7 \pm 1.7$ & $13.8 \pm 1.7$ & $15.7 \pm 2.0$ \\
\hline Theophylline $+\mathrm{NaNO}_{2}$ & $11.1 \pm 1.3$ & $12.7 \pm 1.6$ & $10.5 \pm 1.2$ \\
\hline
\end{tabular}

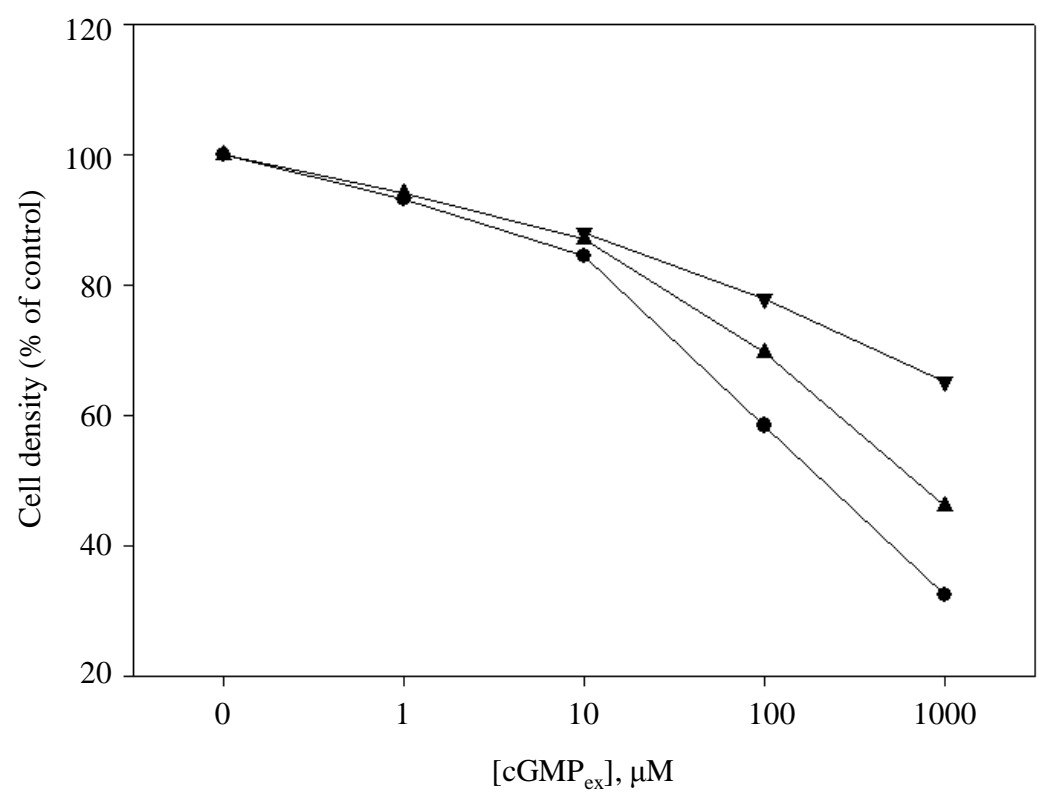

Figure 2. The effect of cGMP-supplemented culture medium on wildtype HEL $(\bullet)$, transfected HEL-MRP5 ${ }^{1}(\boldsymbol{\Delta})$ and HELMRP5 $^{2}(\boldsymbol{\nabla})$ cell densities. The cells were seeded at a concentration of $4 \times 10^{4}$ cells $/ \mathrm{ml}$. The medium was changed daily and supplemented with cGMP $(0,1 \mu \mathrm{M}, 10 \mu, 100 \mu$ and $1000 \mu \mathrm{M})$. The last part of the inhibition curves showed a steeper reduction of densities of $\mathrm{HEL}_{\mathrm{wt}}$ cells (slope $=-26.0, \mathrm{r}=-1.00$ ) than the transfected cells; $\mathrm{MRP}^{1}$ ( $(\mathrm{slope}=-20.5, \mathrm{r}=-0.996$ ) and $\mathrm{MRP5}^{2}$ (slope $\left.=-11.5, \mathrm{r}=-0.998\right)$.

\section{Discussion}

This study with the human erythroleukemia cell line (HEL) was performed based on the consistent finding of increased cGMP plasma levels in other human leukemia [1] and based on our characterization of ATP-dependent cGMP extrusion from human erythrocytes [7] [10] [17]. The report that butyrate increased cGMP efflux from the cancer coli cells [13] attained our attention and raised the question whether this effect existed in HELcells. Butyrate is a short chain fatty acid with a number of biological effects and appear to protect against the development of cancer [16] [18]. In agreement, the present study showed that butyrate caused HEL cell death in concentrations above $100 \mu \mathrm{M}$. To avoid an interference of the antiproliferative effect of butyrate cGMP efflux 




Figure 3. The effect of SNP-supplemented culture medium on wildtype HEL $(\bullet)$, transfected HEL-MRP5 ${ }^{1}(\mathbf{\Delta})$ and HEL$\mathrm{MRP5}^{2}(\boldsymbol{\nabla})$ cell densities. The cells were seeded at a concentration of approximately $3.0 \times 10^{4}$ cells/ml and the medium was changed daily and supplemented with SNP $(1 \mu \mathrm{M}, 10 \mu \mathrm{M}$ and $100 \mu \mathrm{M})$. Linear regression showed a less steep reduction of densities of HEL $\mathrm{wt}_{\mathrm{w}}$ cells (slope $\left.=-8.9, \mathrm{r}=-0.934\right)$ than observed for the transfected cells; HEL-MRP5 ${ }^{1}($ slope $=-20, \mathrm{r}=$ $-0.990)$ and HEL-MRP5 ${ }^{2}$ (slope $=-16.9, \mathrm{r}=-0.989$ ).

was studied for concentrations below $100 \mu \mathrm{M}$. Under the present experimental conditions, butyrate did not affect the HEL cell distribution of cGMP between the extra- and intracellular compartment. This effect appears also to be variable among colon cancer cells. Both T84 cells and Caco-2 cells responded similar, whereas COS cells did not show any enhanced cGMP accumulation [13]. The non-specific cyclic phosphodiesterase inhibitor theophylline tended to increase cGMP levels after exposure to the highest concentrations of butyrate. The potent sCG stimulators SNP and $\mathrm{NaNO}_{2}$ in the presence of theophylline gave a small but marked elevation. The peak concentration of cGMP after SNP stimulation has been reported to occur after 3 - 5 min [19]. A short incubation time was used in the present study to capture the potential concentration peak of cGMP but such peak was not observed in the HEL cells.

Western blot showed an overexpression of MRP5 in the transfected cells. Cyclic cGMP was added to the culture medium to elevate intracellular concentrations but the permeability is counteracted by the activity of MRP5 that is an effective efflux pump [8]. In agreement, low extracellular cGMP concentrations (1.0 - $10 \mu \mathrm{M})$ did not give detectable increase of intracellular concentrations in HEK 293 cells [11] or hRBC [20]. However, these and other studies have shown that cGMP in millimolar concentrations may permeate the membrane from the ectoside. This is consistent with a facilitated inward transport by OAT2 (SLC27A) with a $\mathrm{K}_{\mathrm{m}}$-value of approximately $100 \mu \mathrm{M}$ [21]. However, the employed methods made it unable to detect clear changes in extracellular cGMP levels between wildtype and transfected cells. On the other hand, a marked antiproliferative effect was obtained with an apparent $\mathrm{IC}_{50}$-value of $250 \mu \mathrm{M}$. The antiproliferative potency of cGMP was lower in HEK 293 cells since cGMP concentrations above $1000 \mu \mathrm{M}$ were needed to reduce cell density 50\% [11]. The most important observation in the present study was the reduced sensitivity to cGMP after MRP5 transfection. In addition, the two series of transfection showed a clear difference in sensitivity (HEL-MRP5 ${ }^{1}>$ HEL-MRP5 ${ }^{2}$ ). These results are compatible with the hypothesis that overexpression of MRP5 is a resistance mechanism in some cancer cells to avoid the antiproliferative effect of cGMP. This is also compatible with the idea that plasma cGMP may serve as a surrogate marker for treatment efficiency in leukemic patients [22]. A study of cell lines from cancers of the uterine cervix showed a limited but distinct increase of MRP5 expression during cell growth [23]. This is compatible with the reports of increased urine cGMP levels in patients with an active cancer [3] [4]. High expression of MRP5 and related transport proteins was prognostic unfavorable in acute lymphoblastic leukemia [24]. MRP8 (ABCC11) also represents a cGMP efflux system [25] and may serve as a predictive marker for treatment outcome in acute myeloid leukemia. 
However, the transfected cells were less sensitive to SNP than the wildtype and the sensitivity differed between them (HEL-MRP5 ${ }^{1}>$ HEL-MRP5 ${ }^{2}$ ). In a previous study [11], SNP reduced the intracellular concentration ratio between GSH and GSSG from 260 to 80. An increased expression of MRP5 may favor the export of GS-X (glutathione conjugates) and thereby reduce the cell toxic effects. If nitric oxide analogues like SNP or their cytotoxic metabolites are eliminated, it is possible that the balance between growth inhibitory and stimulatory effects is modified [26].

\section{Conclusion}

The present study suggests that reduced antiproliferative effect of cGMP is associated with increased expression of MRP5, but raises several questions which have to be addressed in future studies to verify the role of MRP5 in the cancer cell cGMP biokinetics.

\section{Conflict of Interests}

There are no conflicts of interests to declare.

\section{References}

[1] Peracchi, M., Bamonti-Catena, F., Lombardi, L., Toschi, V., Bareggi, B., Cortelezzi, A., Maiolo, A.T. and Polli, E.E. (1985) Plasma Cyclic Nucleotide Levels in Monitoring Acute Leukemia Patients. Cancer Detection and Prevention, 8, 291-295.

[2] Turner, G.A., Ellis, R.D., Guthrie, D., Latner, A.L., Monaghan, J.M., Ross, W.M., Skillen, A.W. and Wilson, R.G. (1982) Urine Cyclic Nucleotide Concentrations in Cancer and Other Conditions; Cyclic GMP: A Potential Marker for Cancer Treatment. Journal of Clinical Pathology, 35, 800-806. http://dx.doi.org/10.1136/jcp.35.8.800

[3] Orbo, A., Jaeger, R. and Sager, G. (1998) Urinary Levels of Cyclic Guanosine Monophosphate (cGMP) in Patients with Cancer of the Uterine Cervix: A Valuable Prognostic Factor of Clinical Outcome? European Journal of Cancer, 34, 1460-1462. http://dx.doi.org/10.1016/S0959-8049(98)00079-3

[4] Orbo, A., Hanevik, M., Jæger, R., van Heusden, S. and Sager, G. (2007) Urinary Cyclic GMP after Treatment of Gynecological Cancer. A Prognostic Marker of Clinical Outcome. Anticancer Research, 27, 2591-2596.

[5] Luesley, D.M., Blackledge, G.R., Chan, K.K. and Newton, J.R. (1986) Random Urinary Cyclic 3',5' Guanosine Monophosphate in Epithelial Ovarian Cancer: Relation to Other Prognostic Variables and to Survival. British Journal of Obstetrics and Gynaecology, 93, 380-385.

[6] Turner, G.A., Greggi, S., Guthrie, D., Benedetti, P.P., Ellis, R.D., Scambia, G. and Mancuso, S. (1990) Monitoring Ovarian Cancer Using Urine Cyclic GMP. A Two-Centre Study. European Journal of Gynaecological Oncology, 11, 421-427.

[7] Sager, G., Orbo, A., Pettersen, R.H. and Kjørstad, K.E. (1996) Export of Guanosine 3',5'-Cyclic Monophosphate (cGMP) from Human Erythrocytes Characterized by Inside-Out Membrane Vesicles. Scandinavian Journal of Clinical and Laboratory Investigation, 56, 289-293. http://dx.doi.org/10.3109/00365519609090579

[8] Jedlitschky, G., Burchell, B. and Keppler, D. (2000) The Multidrug Resistance Protein 5 Functions as an ATPDependent Export Pump for Cyclic Nucleotides. The Journal of Biological Chemistry, 275, 30069-30074. http://dx.doi.org/10.1074/jbc.M005463200

[9] Schultz, C., Vaskinn, S., Kildalsen, H. and Sager, G. (1998) Cyclic AMP Stimulates the Cyclic GMP Egression Pump in Human Erythrocytes: Effects of Probenecid, Verapamil, Progesterone, Theophylline, IBMX, Forskolin, and Cyclic AMP on Cyclic GMP Uptake and Association to Inside-Out Vesicles. Biochemistry, 37, 1161-1166. http://dx.doi.org/10.1021/bi9713409

[10] Orvoll, E., Lysaa, R.A., Ravna, A.W. and Sager, G. (2013) Misoprostol and the Sildenafil Analog (PHAR-0099048) Modulate Cellular Efflux of cAMP and cGMP Differently. Pharmacology \& Pharmacy, 4, 104-109. http://dx.doi.org/10.4236/pp.2013.41015

[11] Sager, G., Sundkvist, E., Jaeger, R., Lysaa, R.A. and Fuskevaag, O.M. (2014) Sodium Nitroprusside Inhibits HEK293 Cell Growth by cGMP-Dependent and Independent Mechanisms. Pharmacology \& Pharmacy, 5, 262-271. http://dx.doi.org/10.4236/pp.2014.53033

[12] Martin, P. and Papayannopoulou, T. (1982) HEL Cells: A New Human Erythroleukemia Cell Line with Spontaneous and Induced Globin Expression. Science, 216, 1233-1235. http://dx.doi.org/10.1126/science.6177045

[13] Crane, J.K. (2000) Redistribution of Cyclic GMP in Response to Sodium Butyrate in Colon Cells. Archives of Biochemistry and Biophysics, 376, 163-170. http://dx.doi.org/10.1006/abbi.2000.1703 
[14] Whitt, M., Buonocore, L. and Rose, J.K. (2001) Liposome-Mediated Transfection. Current Protocols in Immunology, 3 , 10.16.1-10.16.4.

[15] Chou, T.C. (1976) Derivation and Properties of Michaelis-Menten Type and Hill Type Equations for Reference Ligands. Journal of Theoretical Biology, 39, 253-276. http://dx.doi.org/10.1016/0022-5193(76)90169-7

[16] Pajak, B., Orzechowski, A.F. and Gajkowska, B. (2007) Molecular Basis of Sodium Butyrate-Dependent Proapoptotic Activity in Cancer Cells. Advances in Medical Sciences, 52, 83-88.

[17] Sundkvist, E., Jaeger, R. and Sager, G. (2002) Pharmacological Characterization of the ATP-Dependent Low K(m) Guanosine 3',5'-Cyclic Monophosphate (cGMP) Transporter in Human Erythrocytes. Biochemical Pharmacology, 63, 945-949. http://dx.doi.org/10.1016/S0006-2952(01)00940-6

[18] Mu, D., Gao, Z.F., Guo, H.F., Zhou, G.F. and Sun, B. (2013) Sodium Butyrate Induces Growth Inhibition and Apoptosis in Human Prostate Cancer DU145 Cells by Up-Regulation of the Expression of Annexin A1. PLoS ONE, 8, e74922. http://dx.doi.org/10.1371/journal.pone.0074922

[19] Schroder, H., Leitman, D.C., Bennett, B.M., Waldman, S.A. and Murad, F. (1988) Glyceryl Trinitrate-Induced Desensitization of Guanylate Cyclase in Cultured Rat Lung Fibroblasts. Journal of Pharmacology and Experimental Therapeutics, 245, 413-418.

[20] Flo, K., Hansen, M., Orbo, A., Kjørstad, K.E., Maltau, J.M. and Sager, G. (1995) Effect of Probenecid, Verapamil and Progesterone on the Concentration-Dependent and Temperature-Sensitive Human Erythrocyte Uptake and Export of Guanosine 3',5' Cyclic Monophosphate (cGMP). Scandinavian Journal of Clinical and Laboratory Investigation, 55, 715-721. http://dx.doi.org/10.3109/00365519509075401

[21] Cropp, C.D., Komori, T., Shima, J.E., Urban, T.J., Yee, S.W., More, S.S. and Giacomini, K.M. (2008) Organic Anion Transporter 2 (SLC22A7) Is a Facilitative Transporter of cGMP. Molecular Pharmacology, 73, 1151-1158. http://dx.doi.org/10.1124/mol.107.043117

[22] Peracchi, M., Toschi, V., Bamonti-Catena, F., Lombardi, L., Bareggi, B., Cortelezzi, A., Colombi, M., Maiolo, A.T. and Polli, E.E. (1987) Plasma Cyclic Nucleotide Levels in Acute Leukemia Patients. Blood, 69, 1613-1616.

[23] Eggen, T., Sager, G., Berg, T., Nergaard, B., Moe, B.T.G. and Orbo, A. (2012) Increased Gene Expression of the ABCC5 Transporter without Distinct Changes in the Expression of PDE5 in Human Cervical Cancer Cells during Growth. Anticancer Research, 32, 3055-3061.

[24] Plasschaert, S.L., de Bont, E.S., Boezen, M., vander Kolk, D.M., Daenen, S.M., Faber, K.N., Kamps, W.A., de Vries, E.G. and Vellenga, E. (2005) Expression of Multidrug Resistance-Associated Proteins Predicts Prognosis in Childhood and Adult Acute Lymphoblastic Leukemia. Clinical Cancer Research, 11, 8661-8668. http://dx.doi.org/10.1158/1078-0432.CCR-05-1096

[25] Guo, Y., Kock, K., Ritter, C.A., Chen, Z.S., Grube, M., Jedlitschky, G., Illmer, T., Ayres, M., Beck, J.F., Siegmund, W., Ehninger, G., Gandhi, V., Kroemer, H.K., Kruh, G.D. and Schaich, M. (2009) Expression of ABCC-Type Nucleotide Exporters in Blasts of Adult Acute Myeloid Leukemia: Relation to Long-Term Survival. Clinical Cancer Research, 15, 1762-1769. http://dx.doi.org/10.1158/1078-0432.CCR-08-0442

[26] Napoli, C., Paolisso, G., Casamassimi, A., Al-Omran, M., Barbieri, M., Sommese, L., Infante, T. and Ignarro, L.J. (2013) Effects of Nitric Oxide on Cell Proliferation: Novel Insights. Journal of American College of Cardiology, 62 , 89-95. http://dx.doi.org/10.1016/j.jacc.2013.03.070 